\title{
Women's art in Ireland and Poland 1970-2010: Experiencing and Experimenting on the Female Body
}

\section{Valérie Morisson}

\section{(2) OpenEdition}

\section{Journals}

Electronic version

URL: https://journals.openedition.org/etudesirlandaises/3169

DOI: 10.4000/etudesirlandaises.3169

ISSN: 2259-8863

Publisher

Presses universitaires de Caen

Printed version

Date of publication: 30 October 2012

Number of pages: 81-94

ISBN: 978-7535-2158-2

ISSN: 0183-973X

\section{Electronic reference}

Valérie Morisson, "Women's art in Ireland and Poland 1970-2010: Experiencing and Experimenting on the Female Body", Études irlandaises [Online], 37-2 | 2012, Online since 30 October 2014, connection on 01 August 2022. URL: http://journals.openedition.org/etudesirlandaises/3169 ; DOI: https://doi.org/ 10.4000/etudesirlandaises.3169

This text was automatically generated on 1 August 2022.

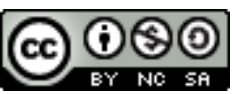

Creative Commons - Attribution-NonCommercial-ShareAlike 4.0 International - CC BY-NC-SA 4.0 https://creativecommons.org/licenses/by-nc-sa/4.0/ 


\title{
Women's art in Ireland and Poland 1970-2010: Experiencing and Experimenting on the Female Body
}

\author{
Valérie Morisson
}

\section{Introduction: Tradition and Resistance}

1 Though the Polish minority is the most numerous one in Ireland, and although the Ireland Poland Cultural Foundation has been in existence for five years, comparative studies centered on the two cultures remain sparse. However, confronting trends in Irish culture with evolutions in countries which offer similar characteristics may strengthen our understanding of the interactions between art and society. The genderrelated works produced by Irish and Polish female artists between 1970 and 2010 reflect a growing tension between traditional values, secularisation and Europeanisation. They reverberate the heated debates over abortion, contraception and divorce which have put womanhood in the limelight in these two deeply Catholic nations.

2 These lens-based works derive from the tradition of self-portraiture and are related to body art. They starkly highlight the corporeality of the body, thus challenging the patriarchal social structures and discourses that, according to many radical feminists ${ }^{1}$, compound masculine power. Crucial to the understanding of these works is Foucault's argument that "there are no relations of power without resistances; the latter are all the more real and effective because they are formed right at the point where relations of power are exercised ${ }^{2}$. Since the body is the main target of power, art works using the female body as their prime material are likely to shake the audience's perceptions of femininity, whether it is perceived as womanhood, femalehood, or motherhood. The performative body, serving a re-empowerment strategy, then becomes a locus of resistance. Irish artist Helena Walsh observes that the recent development of live art in Ireland has been "hugely significant to countering the negative impact of strict cultural mores and giving voice to those bodies silenced by the nation state ${ }^{3 "}$. Live art is 
particularly prone to shatter ingrained beliefs and triggers a dialogue between the artist and the viewers through emotional representations. However, the dissemination and recognition of such art is fairly recent both in Poland and in Ireland ${ }^{4}$ given that national art galleries have for a long time favored oil painting and sculpture ${ }^{5}$.

Back in the 1970s and 1980s, Irish and Polish female artists were working in significantly different contexts. In Poland, Barbara Falender, Alina Szapocznikow, and Ewa Partum flouted artistic conventions by unraveling the female sex. In 1978, one of the first feminist exhibitions was held at the Arsenal Gallery in Poznan. The same year, Natalia LL organized her seminal show, Women's Art, at the Jatki Gallery PSP, in Warsaw. While such artistic ventures failed to reach a large audience and remained isolated initiatives $^{6}$, they proved inspirational for the next generation ${ }^{7}$. In the early 1990s, their Irish counterparts (Dorothy Cross, Alanna O'Kelly, Rita Duffy, or Alice Maher) focused more on local issues than on mainstream feminism and emphasized the collusion between nationalism and Catholicism, avoiding any overt allusion to sexuality. In Ireland, within the art world, no feminist avant-garde offered a radical discourse. Nevertheless, in spite of these diverging contexts, over the last decades of the $20^{\text {th }}$ century, female artists in both countries have increasingly staged their bodily existences. They have desecrated idealized nudity, they have pictured women's sexual pleasure more openly, and have had to come to terms with reactionary backlashes.

\section{The Endoscopic Gaze: From the Allegorical to the Anatomical}

Both in Poland and in Ireland, many female artists have subverted the traditional allegorical depictions of the female body. In Ireland, women "have been recognized, not as subjects with their own identity, but have instead been reduced to symbols of the nation ${ }^{8}$. Mother Ireland strangely resembles Mother Poland as both figures disseminated models of women whose lives were fulfilled only in their homes, thereby guaranteeing the integrity of the family and the nation ${ }^{9}$. In nationalist imagery, in both countries, women's carnal bodies are negated.

While in the 1970s, American and European feminist artists had drawn attention to their gendered bodies in a radical, physiological way ${ }^{10}$ and claimed that "con is beautiful" 11 , in Ireland, feminist art was blossoming in a muted, metaphorical way throughout the 1990s. Pauline Cummins and Louise Walsh's video installation, Sounding the Depths (1992, IMMA, Dublin) is made up of photographs of compressed mouths, as well as of a video showing shells, then shouting or laughing mouths, and shots of the artists' bellies onto which are projected their open mouths. The work revisits both the myth of the vagina dentate, the medieval motif of the Sheela-na-gigs, and the local Molly Malone. The use of bodily imagery is effective: "Sounding the Depths refuses the silencing of women - embracing instead a defiant imagery that conveys the rage and sexuality of women's voices ${ }^{12}$." The utter physicality of the woman's womb-cum-vagina is used as a re-appropriation strategy. "As the woman gazes down into herself there is no gaze that concerns her except for her own. The 'male gaze' [...] grazes on the surface of the body", the artists commented ${ }^{13}$. The visceral body, one deeply felt by women rather than beheld by men, replaces the smooth surface of the idealized allegorical woman. The laughter and cries that resonate in the gallery echo the public rumors that spread in the media throughout the 1990s as women's sexuality was increasingly alluded to in 
Ireland ${ }^{14}$. Sounding the Depths illustrates the artists' belief that "everyone's body is their own territory and that interference from church or state shouldn't be tolerated ${ }^{15}$ ". It explores the conflation of intimate body and gender politics, joining thereby one of the major trends in feminist art:

it is precisely this denial of women as "speaking subjects" that women in performance art both foreground and subvert. The intensely intimate nature of the work, the emphasis on personal experience and emotional material, not 'acted' or distanced from artist or audience, is what most characterises this alternative, heterogeneous voice ${ }^{16}$.

6 Avoiding the pitfalls of essentialism, the work exemplifies Hélène Cixous' definition of feminine writing as a form of expression that privileges the voice and that allows images of the body to surface ${ }^{17}$. Feminist theoreticians do envision the body as "a signifying medium, a mode of rendering public and communicable what is essentially private" and as "a circuit for the transmission of information from outside the organism ${ }^{18}$ ". Pertaining to this trend, Sounding the Depth presents the body, subsumed in the vagina metaphor, as an interface and locus of resistance to male power.

In a 1995 film, Alicja Zebrowska, a highly controversial Polish artist, provides a more straightforward vision of female genitalia. Mystery is Looking is tightly focused on a vagina that is contracted, opens up, and eventually reveals a life-like glass eye. Hairless and made-up, the vagina is eerily metamorphosed into an eye, the lips moving like eyelids. The quasi-surrealist visual language proves strongly political as the vagina literally stares back, defying masculine scopophilia. In Original Sin (1993-94), Zebrowska evokes masturbation before focusing on a vagina from which a Barbie doll is born. The apple aroma that floats in the room, as well as the apple the artist bites in suggest a religious interpretation ${ }^{19}$. Like in other works using the Barbie doll as a symbol of the commodification of the female body, the social constraints imposed upon women in capitalist societies are clearly denounced ${ }^{20}$. The depiction of a parodistic delivery also explicitly refers to the stress, suffering and tragedies to which Polish women have fallen prey due to restrictive anti-abortion laws "making them live in incessant dread of unwanted pregnancy and with a near-paranoid apprehension of their sexuality" ${ }^{21}$ ". Walsh, Cummins, and Zebrowska follow in the footsteps of the previous generation of feminist artists who had subverted the masculine modernist aesthetic hierarchies by

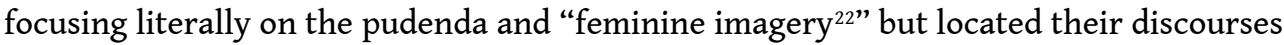
in the political.

8 In Poland and Ireland, where the influence of the clergy upon gender politics has been considerable, the Church is repeatedly summoned in women's art on account of its political role in the debates over abortion, contraception or divorce ${ }^{23}$.

9 For a long time in Ireland, both Church and state have "maintained that women should hold a certain morality, particularly relating to areas of sexuality and reproduction ${ }^{24 "}$. As the Health Family Planning Bill was debated in the late 1970s and early 1980s, the Roman Catholic Church hampered the passing of a liberal law on contraceptives. In 1971, after a group of feminists travelled by train from Belfast to Dublin laden with contraceptive devices, the Bishop of Clonfert equated their action to an onslaught on the Catholic heritage of Ireland ${ }^{25}$. However, in 1979, the Supreme Court eventually legalized contraception.

10 In Poland and Ireland alike, the Catholic Church took part in the debates over abortion. In Ireland, where abortion has been a criminal offense since 1861, back-street abortions 
were numerous and many young women travelled to England to terminate their unwanted pregnancies. In 197926, while in Limerick, Pope John Paul II said: "May Ireland never weaken in her witness, before Europe and the whole world, to the dignity and sacredness of all human life, from conception until death ${ }^{27}$." Shortly after this visit, as some of the Catholic right-wing intended to make Ireland an example of pro-life values, the Pro-Life Amendment Campaign was launched and abortion became the issue around which the maximum support for traditional values could be generated ${ }^{28}$. In 1983, the Eighth Amendment introduced a constitutional ban on abortion, whereupon Ireland became unique among Western countries in that it took action to strengthen legal prohibitions ${ }^{29}$. Still, abortion was not debated as a gendered issue and proved divisive among women's organizations ${ }^{30}$. In the 1990s, at a time when all information on abortion was illegal in Ireland, the " $\mathrm{X}$ case" put abortion back on top of the political agenda and generated much outcry ${ }^{31}$. The 1992 referendum brought out two amendments: the right to travel to get an abortion and the right to information. The CCase (1997-1999), with its emphasis on rape and women's health, further isolated Ireland in Europe ${ }^{32}$.

11 In communist Poland, abortion was legalized in 1956. The emancipation of women was then tied to industrial manufacturing and farming at a time when the "women on tractors" slogan was popular. Contrary to Ireland, which at that time strove to maintain women in the domestic sphere, Poland willingly put women to work but remained a patriarchal society where sexism and discrimination persisted ${ }^{33}$. It is hardly surprising therefore to see a re-surfacing of identity issues and gender-related debates in post-communist Poland. Abortion was among the first questions raised by many post-socialist governments of Eastern Central Europe ${ }^{34}$. The Unborn Child Protection Bill, which was discussed shortly before the Pope's 1991 visit to Poland, was eventually rejected. However, in 1993, one of the most restrictive legislations on abortion in Europe was passed ${ }^{35}$.

12 Against this backcloth, women artists from the two countries have striven to invalidate the assumption that "motherhood is intrinsic to adult female identity ${ }^{36 " . ~ T h e ~ d e b a t e s ~}$ on abortion, as well as the soaring divorce rates ${ }^{37}$ and higher employment rates for Irish women after Ireland joined the EU have been crucial to "new personal freedoms and the emergence of different female identities ${ }^{38 "}$. If artworks mirror these evolutions, attempts to limit artistic freedom in Poland in the 1990s may be interpreted as a crisis in women's rights ${ }^{39}$ with works by Dorotha Nieznalska or Katarzyna Kozyra sparking fierce protest ${ }^{40}$. On the contrary, the declining influence of the Church in post Celtic-tiger Ireland and a waning nationalism seem to have made it easier for artists to show how religious discourse and nationalism have oppressed women by idealizing motherhood.

13 Amanda Coogan parodies images of the Madonna and Child in her Madonna Series. In Mad with Child (2007), the artist in a close-fitting evening dress looks embarrassed as she is breast-feeding a child. Helena Walsh, who is deeply aware of the interference between politics and women's intimate lives, "utilises abject biological functions to subvert gendered ideologies ${ }^{41}$ ". In MOM, Marks of Motherlands (see figure 1), she addresses motherhood and breastfeeding, thereby subverting nationalist ideals and allegorical representations. She alludes to her desire to "explore the effects of the overwhelming impact of the nation state's continuing rigid moral policing of female reproductive autonomy $\mathrm{y}^{42}$ ", which had negatively shaped her view of motherhood as "a 
form of entrapment/control ${ }^{43}$ ". In MOM, walking within a small space delineated by empty baby bottles, she stuffs herself with a bottle brush before using a bottle as a cow tit or a penis. At the end of the performance, the bottles are scattered on the floor while the artist, her breast bandaged, frantically cleans them. The performance includes a video alluding to the artist's grandparents' life on a farm in rural Ireland. This device brings together motherhood and the rural nationalist ideal. Walsh, who calls herself a feminist, constantly bases her work on the history of women in Ireland:

I feel certainly the abundance of idealised representations of women in contemporary visual culture has always and still does somewhat impinge negatively on the cultural view of women - but I feel the inherent liveness and the degree of personal control enabled through performance is effective in combating such imagery ${ }^{44}$.

14 Consuming Colonies, in which the artist displays her own placenta after the birth of her child, exemplifies Michelle Brewer's claim that "through enshrinement of the pro-life stance in the laws of Ireland Irish women are themselves colonized ${ }^{45}$ ". Many works by women artists deconstruct political ideologies by using the condition of their own lives, therefore "unmasking the system of representation and its ideological alliances ${ }^{46}$ " which is particularly overwhelming in Ireland and Poland, where nationalism has lastingly shaped femininity.

\section{Nakedness, or Nudity Revisited}

\section{Los Angeles-based artist Cheri Gaulke explained that}

performance is not a difficult concept to us [women]. We're on stage every moment of our lives. Acting like women. Performance is a declaration of self -who one is... and in performance we found an art form that was young, without the tradition of painting or sculpture. Without the traditions governed by men. The shoe fit, and so, like Cinderella, we ran with $\mathrm{it}^{47}$.

Contemporary Cinderellas have ridden themselves of aprons and bodices. Because the female body has been mostly looked at, to the point of connoting "to-be-looked-atness ${ }^{48}$ ", women artists now actively look at their own naked bodies through the lens, paying particular attention to the distance between their bodies and the spectators. In several works, idealized nudity is replaced by stark, unbeautified nakedness, eschewing man's desire. Flouting the conventions of the female nude further, some artists let their body overflow with various substances and reveal what is normally hidden behind the surface of their skins.

Performing naked in public spaces is a subversive practice which requires the artistic legitimization of supportive artistic groups or galleries. In the late 1970s, Polish artist and poet Ewa Partum worked with and on her naked body during street interventions and actions. In Women! Marriage is Against You (1980), she called women to liberate themselves from married slavery. In Tautological Cinema, she appeared silenced by straps on her mouth. Partum endorsed the idea, then disseminated through liberationist feminist discourse, that women's oppression and subordination originate in patriarchal social structures that construct and reinforce men's domination. Yet she used her own body as a tool of resistance to man's power, founded and ran a gallery of mail art and art theory in Lodz in 1972, and published manifests. Her Poem by Ewa evidences her interest in finding a new language apt to re-shape female identity. Partum paved the way for the future generations of Polish female artists at a time when 
no similar model was available for their Irish counterparts. Though they do not embrace radical feminism as unreservedly as Partum did, younger Polish artists similarly reduce the distance between the onlooker and the naked model, thereby tackling voyeurism and toying with the physiological/sensual divide.

In two related works filmed in Budapest's bathhouses, Katarzyna Kozyra explores the socially constructed perceptions of the naked body. Woman's Bathhouse (1999) displays the unidealized naked bodies of female bathers that thwart the male-produced cliché of Oriental bathers. In Men's Bathhouse, a video documents Kozyra's transformation into a man, the fitting of a beard and a prosthetic penis. Cross-dressing is part and parcel of the self-portrait tradition but postfeminism and queer culture now prolong the masquerade genre as:

women's performance art provides paths to alternatives, to new concepts of difference, subverting the canon of codified sexuality imbedded in centuries of theatre and cultural works, and revealing binary sexuality as another construction complicit in the oppression of women and their full exploration of female sexuality ${ }^{49}$.

19 In Onone (1995-1999), a video performance organized in several acts, Alicja Zebrowska transformed herself into a hermaphrodite thanks to a prosthesis. Owing to its dreamlike atmosphere, the work invites the viewers to investigate their own phantasms, possibly colliding with culturally shaped images of the natural body. Onone interrogates our acceptance of norms and spurs us to rethink normalcy and deviancy. Travestism is recurrent in Zebrowska's work and constitues an irate response to the increasing homophobia and discrimination against sexually deviant people in contemporary Poland ${ }^{50}$.

Whereas in Poland, women artists followed in the footsteps of Partum, in Ireland performance was neglected and considered a subversive genre ${ }^{51}$. It was foreign artists who inspired women performers: Marina Abramovic performed Rest Energy in Dublin in 1980 ; Polish performance artist Warpechlowski visited Ireland in $1982^{52}$. Marina Abramovic's body art influenced Amanda Coogan and Kira O'Reilly, both of whom stage their bare bodies to subvert the canon as physicality supersedes the passivity of the painter's model. The two artists ceaselessly enhance the physiological presence of the body that Foucault repeatedly alluded to: "deployments of power are directly connected to the body - to bodies, functions, physiological processes, sensations, and pleasures ${ }^{53}$." In Amanda Coogan's durational performance, Yellow Series, the artist struggles to free herself from a web of fabric, her physical pain and endurance puzzling the viewer. In Snails, after Alice Maher (2010), the snails that glide on her naked body leave their sticky secretions on her skin ${ }^{54}$. As to Kira O'Reilly, she seems to have a preference for leeches, far more harmful creatures that suck the artist's blood and leave traces on her skin. In Untitled (Syncope) ${ }^{55}$, the artist in high red stiletto shoes and a feather headdress dances clumsily in front of the audience before removing her props and re-exploring the vaults of the station enjoying a new freedom. Through eyecontact O'Reilly involves the viewers into her action forcing them to adapt to the uncanny presence of her naked body. Adding to the 100 or so wounds that she inflicts to herself when performing Succour, she also cuts her calves. The artist confesses to being fascinated by the scars and the healing process ${ }^{56}$. In her performances, the body is not a flat cultural surface onto which a passive viewer may project his own desires; the flesh is scarred and "holds strong connotations of social violence, outsider status, of negativity 57". In other performances (Quiver, The Cat Show, Cardiff ; or Untitled, 2009, 
VIVID festival, Endurance, Birmingham) O'Reilly opposes the smoothness and warmth of her sensual body to the cold rigidity of the architecture. The artist is interested in "how the physical stuff of body is a vehicle of cultural meaning, and how culture produces bodies ${ }^{58}$ "; she considers the body as "material and site in which narrative threads of the personal, sexual, social and political knot and unknot in shifting permutations ${ }^{59}$ ".

21 Polish artist Teresa Tyszkiewicz evokes self-mutilation but in a metaphorical way only, covering her face with pins or red stripes of fabric. Like O'Reilly's more physical performances, these works bring to mind Catholic martyrs and the sacrifices made by women to match men's expectations in terms of beauty. Irish artists equally show the female visceral body in an unpalatable way: 50 ways to lose your love handles, a 2003 film by Amanda Coogan is an ironical comment on female beauty. In A Room with a View, Helena Walsh throws the content of an unflushed toilet bowl on the window pane of a reconstituted bathroom where she stands exposed to the gazes of passer-bys while Ingeminated Battology, a video by Jenny Keane, is made up of two tight close-ups of the artist's uglified mouth chewing black ink. The female body is de-eroticized as these women performers combine "active authorship and an elusive medium to assert [their] irrefutable presence (an act of feminism) within a hostile environment (patriarchy) ${ }^{60 "}$. Jeanie Forte stressed the subversive effect of strategies based on physical corporeality:

The semiotic havoc created by such a strategy combines physical presence, real time, and real women in dissonance with their representations, threatening the patriarchal structure with the revolutionary text of their actual bodies ${ }^{61}$.

The naked body is a potent material, connected as it is to sexual desire and social and cultural representations of sexuality.

\section{Sex in the Mind's Eye}

As the 1970s sexual liberation movement denounced male fetishism and the repression of women's sexual desire, in Ireland and Poland the re/presentation of female sexuality raised specific questions. In Poland, several works depicting sexuality triggered controversies but alternative private spaces offered artists opportunities to create avant-garde feminist works ${ }^{62}$. Natalia Lach Lachowicz, who co-founded an artistic group and gallery called PERMAFO in 1970, became one of the standard-bearers of the international feminist art movement. She subsequently distanced herself from a movement which, she believed, could imprison her "in the claws of vagina and uterus ${ }^{63 "}$. Straddling the line between art and pornography, in Natalia 1st Sex, (1974), the artist assembled photographic nudes in pornographic positions while her iconic Consumer Art and Post-Consumer series delve into eroticization and auto-eroticism. On account of their disproportionate sizes and of the repetitions of images showing a woman eating a banana, a sausage or spitting out cream, these works turn the intimate into something disturbingly public. Voyeurism and exhibitionism are entwined in Impressions (1973), a slightly blurred film featuring the artist exploring her naked body, shaking her breast energetically as they are splashed with a white liquid that may evoke either milk or man's semen. In the 1970s, Western feminist critics identified such works as feminist because they depicted women as active subjects of pleasure. Teresa Tyszkiewicz, a Polish artist then showing at the Warsaw Contemporary Gallery, also made erotically-charged films between 1979 and 1982, at a time when prudery and 
puritan values were prevalent. The Martial Law, imposed in Poland in December 1981, subsequently made it almost impossible for artists to produce such radical works and the 1980 s saw a return to painting ${ }^{64}$.

In Ireland, the permissive society took longer to be accepted"5: "Irish social standards and Irish legislation have never embodied principles and behaviours that respect the sexual rights of women ${ }^{66}$."Sexual pleasure is seldom overtly evoked in art. Helena Walsh, who performed naked in several works acknowledges that "it would have been difficult to present the explicit or naked female body" at a time when the Magdalene Laundries still existed ${ }^{67}$. "It is still not common for mainstream galleries to take on explicit or provocative body-based works", she adds in spite of the increasing influence of red-light entertainment ${ }^{68}$.

In the 1990s, in Poland and Ireland alike, artists started exploring the visitors' tacit involvement in the emergence of the erotic. In the mid 1990s, after the ban on abortion in Poland, one could observe "the closure of any possibilities for sexual education and a renewed treatment of woman's sexuality as something shameful, a social taboo ${ }^{69}$ ". Many Polish and Irish women artists have thence trodden dauntlessly on pornographic or erotic art. What Laura Mulvey identified as "the voyeurist-scopophilic look ${ }^{70}$ " was indeed used to probe the artist's and the viewers' sexual phantasms. Inter-iconicity became recurrent and the exhibitionist aspect of former works gave way to more subtle revelations as gazing and glancing were put at the core of artistic processes. In Medea (IMMA, 2001) Amanda Coogan, in a long blue satin dress, places her hand right on her sex revisiting Manet's depiction of the courtesan. O'Reilly's Inthewrongplaceness (Newlyn Gallery, Penzance, 2006) involves the viewers radically. The visitors are admitted in a bedroom where the artist is sitting naked, a dead pig on her lap, and are invited to touch the skin of the animal or of the artist using plastic gloves. Izabella Gustowska's sculptural video installation, Passions and Other Cases (2000), also puts the viewer in the place of a voyeur as he is invited to peep into large glass cocoons with hinged covers that house video screens showing black and green films of hetero or homosexual intercourse. Today's art by women goes beyond the purely feminist to address the wider issue of the reification of the other in forms that are far less assertive and attuned to post-feminism.

\section{Conclusion}

Our comparative investigation leads us to conclude that while political and historical differences do foster artistic differences, art practices and creativity are also highly dependent upon the art system, the existence of collective projects and the presence of exhibition spaces. For some truly activist art to blossom, some form of network, even though it is an underground one, is necessary. As early as the 1970s, within a wide feminist theoretical context collaborative practices emerged as alternatives to the manly authoritative structures of modernist art. Women artists have collaborated earlier in Poland than in Ireland. Warsaw was a catalyst in the 1970s. Zofia Zulik studied at the Warswa Academy of Fine Arts and managed the Private Studio of Art Activities. Barbara Kanopka was member of the Sternenhoch group ${ }^{71}$. Ewa Partum set up a feminist group and created the Adres Gallery in Lodz in 1972. The Prywstna Caleria Sztuki PI in Kracow or Barbara Kozlowska's Babel Gallery consolidated a network of institutions that supported avant-garde artists. No such network existed at the time in 
Ireland. In 1987, Pauline Cummins created the Women Artists Action Group which intended to promote the works of women artists from Ireland. In 2007, the Performance Collective gathered artists dedicated to live art practices. It took artists longer to set up a system that could promote underground practices and help establish an avant-garde tradition.

Figure 1: Helena Walsh, MOM: Marks of Motherlands, The Zaz Festival, Tel Aviv 2007.

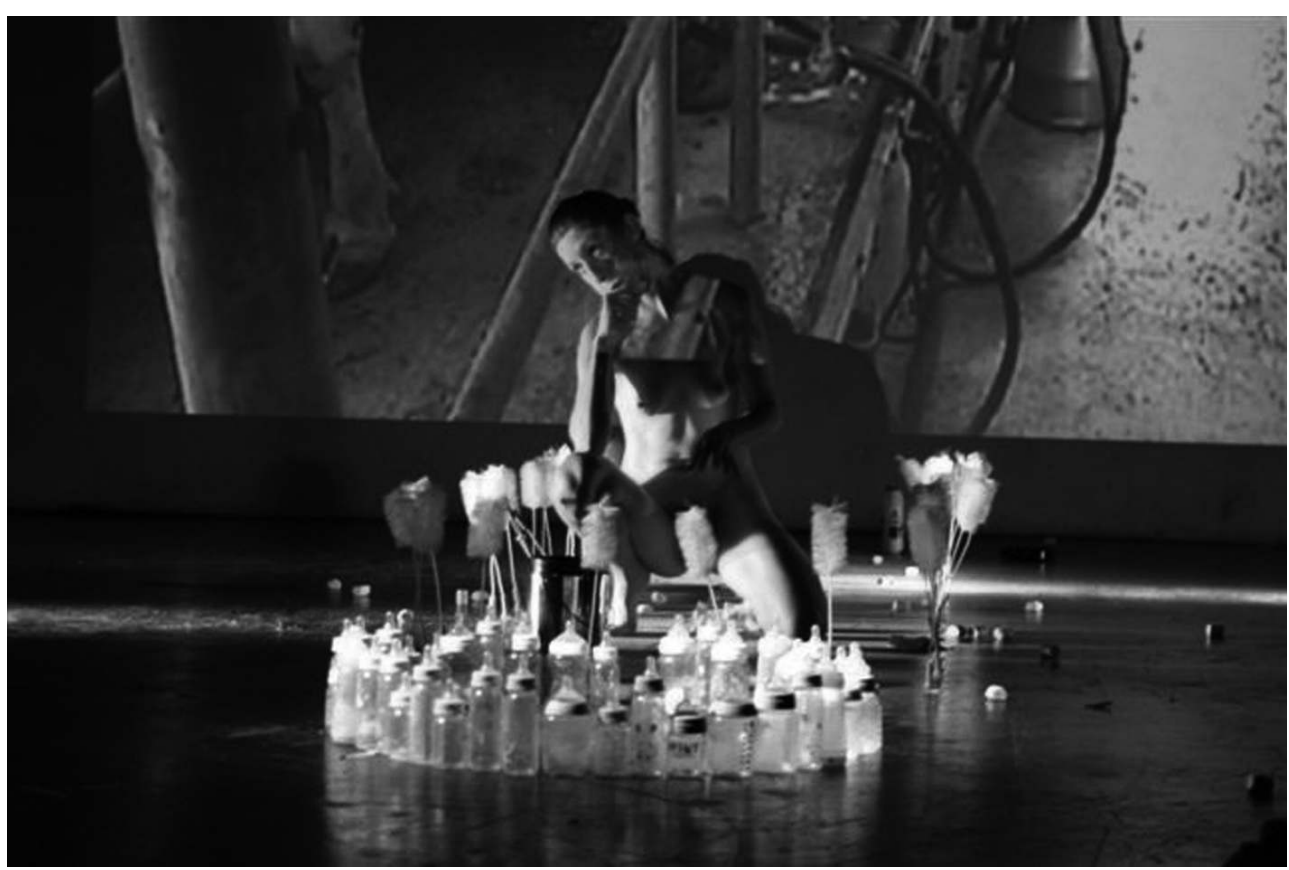

\section{NOTES}

1. See L. R. Lippard's seminal essays: From the Center: Feminist Essays on Women's Art, New York, Dutton and Co, 1976; Issue: Social Strategies by Women Artists, Institute for Contemporary Art, London, 1980.

2. Michel Foucault, "Body/Power" and "Truth and Power" in C. Gordon (ed.), Michel Foucault: Power / Knowledge, Harvester, 1980, p. 142.

3. Interview with the artist, June 2010, quoted with her permission.

4. A showcase of live art at Kilmainham Gaol, Dublin, Right Here, Right Now, 2010, showed performances by 20 artists. Labour, Derry and London, 2012 gathers the most prolific women performance artists in Ireland.

5. See Grigar, Ewa, The Gendered Body as Raw Material for Women Artists of Central Eastern Europe in the Post-Communist Decade, School of the Art Institute, The Havighurst Center for Russian and Post-Soviet Studies, March 2001, [

http://www.units.muohio.edu 
], accessed March 2012.

6. Agata Jakubowska, "The Attractive Banality of Natalia LL's "Consumer Art" (19721975)",

Nordlit : Tidsskrift i litteratur og kultur

, No. 21, 2011, p. 241, [

http://www.ub.uit.no/baser/septentrio/index.php/nordlit/article/viewFile/1763/1645

], accessed March 2012.

7. For a general outlook on Polish art see Aneta Szylak, Architectures of Gender: Contemporary Women's Art in Poland, Warsaw, National Museum of Warsaw, 2003.

8. Gerardine Meaney, "Sex and Nation: Women in Irish Culture and Politics", in A Dozen Lips, Dublin, Attic Press, 1994, p. 188-204, p. 203.

9. Stanislaw Wyspiański's 1905 Maternity, reproduced on a stamp in 1983, like Maurice MacGonigal's 1942 Bean agus a Naoidheanán, exemplifies nationalist rural Catholic ideologies.

10. See Shigeko Kubota's Vagina Painting (1965), Judy Chicago's Red Flag (1971), Carolee Schneemann's Interior Scroll (1975), and Judy Chicago's The Dinner Party (1979).

11. See Amelia Jones, "The Sexual Politics of The Dinner Party - A Critical Context", in Norma Broude and Mary D. Garrand (dir.), Reclaiming Female Agency - Feminist Art History After Postmodernism, Los Angeles and London, University of California Press, 2005, p. 409-433.

12. Grinnell, Jennifer and Conley Alston (ed.), Re/Dressing Cathleen: Contemporary Works from Irish Women Artists, Boston, McMullen Museum of Art - Boston College, 1997, p. 40.

13. Ibid., p. 119.

14. Stories of rapes appeared on national television, Roddy Doyle's TV drama, Family (1994), contributed to a national awakening and sparked off public debates, as did Louis Lentin's documentary, Dear Daughter (1996), tackling sexual abuse in orphanages.

15. Grinnell and Conley, op. cit., p. 119.

16. Jeanie Forte, "Women's Performance Art: Feminism and Postmodernism", Theatre Journal, Vol. 40, No. 2 (May, 1988), The Johns Hopkins University Press, p. 217-235.

17. Hélène Cixous, "The Laugh of the Medusa", in Elaine Marks and Isabelle de Courtivron (ed.), New French Feminisms, New York, Schocken Books, 1981, p. 876.

18. Elizabeth Grosz, Volatile bodies: Toward a Corporeal Feminism, Bloomington, Indiana University Press, 1994, p. 9.

19. Due to its outright reference to Catholicism, Alicja Zebrowska's footage was censored by state-owned art institutions.

20. Because the political histories of the two countries are different, in Ireland gender issues are not related to capitalism and consumerism but rather to poverty.

21. Pawel Leszkowicz, "On Both Sides Of The Mirror. In Search of Sexuality of The Third Millenium", [

http://www.onone.art.pl/bibliography/leszkowicz.html

], accessed March 2012.

22. See Judy Chicago and Miriam Schapiro, "Female Imagery", Womanspace Journal, Summer 1973, p. 11-17. 
23. G. Mrugala, "Polish family planning in crisis: the Roman Catholic influence", Planned Parenthood in Europe Planning familial en Europe (1991), vol. 20, Issue 2, p. 4-5, p. 4.

24. Mary Ryan, "Stepping Out from the Margins: Ireland, Morality, and Representing the Other in Irish Chick Lit.", Nebula 7.3, September 2010, p. 137, available at [

http://www.nobleworld.biz/images/Ryan.pdf

] and "A Feminism of Their Own?: Irish Women's History and Contemporary Irish Women's Writing”, Estudios Irlandeses, No 5, 2010, p. 92-101.

25. June Levine, "Sisters: the personal story of an Irish feminist" in Field Day's Anthology of Irish Writing, vol. V, Irish Women's Writing and Traditions, New York University Press and Cork University Press, 2002, p. 200-201, p. 201.

26. The Pope visited Poland the same year and equally influenced people's attitudes towards abortion.

27. Jenny Beale, Women in Ireland: Voices of Change, Bloomington, Indiana University Press, 1987, p. 60.

28. Brian Girvin, Social Change and Moral Politics: the Irish Constitutional Referendum 1983- 1986, Political Studies,

vol. 34, Issue 1 ,

p. 61-81, March 1986, p. 61.

29. See Evelyn Mahon, "Abortion debates in Ireland: an ongoing issue", in Abortion Politics, Women's Movement, A Comparative Study of State Feminism, Oxford University Press, 2001, p. 157-180.

30. Ibid., p. 164 and 157.

31. Idem.

32. See Elizabeth Wicks, A, B, C v Ireland: Abortion Law under the European Convention on Human Rights, Oxford Journals, Human Rights Law Review, vol. 11, Issue 3, p. 556-566.

33. Belinda Cooper, "Building Feminism from the Ground up", Civnet's Journal for Civil Society (August-September 1997), [http://www.civnet.org/journal/issue3/cfbeco.htm], p. 1.

34. Magdalena Zolkos, "Human Rights and Democracy in the Polish Abortion Debates: Concepts, Discourses, Subversions”, Essex Human Rights Review, vol. 3, No. 1, 2005.

35. Under this law, abortion is allowed only when there is justifiable suspicion that the pregnancy constitutes a threat to the life or a serious threat to the health of the mother, that the fetus is irreversibly damaged, or that the pregnancy resulted from an illegal act.

36. Mardy S. Ireland, Reconceiving, Separating Motherhood from Female Identity, New York, The Guilford Press, 1993, p. 1.

37. According to Statistical Office of European Union (EU) Eurostat - divorce rate in Poland is equal 1.2 divorces per 1000 residents. The average marriage rate in EU present members is 5.1 marriages per thousand. In Ireland, the ban on Divorce was lifted after the Divorce referendum in 1995: the Fifteenth Amendment of the Constitution Act, was signed into law in June 1996.

38. Ireland, op. cit., p. 5.

39. Izabela Kowlaczyk, "Feminist Art in Poland", n.paradoxa, online issue 11, October 1997, p. 12-18, p.14. 
40. See Susan Altmann, Comparative Perspectives Symposium : Feminist Art and Social Change Artists on Trial: Feminist Art in Poland - Between Censorship and Activism, 2008, vol. 33, No. 2, p. 413-418, Chicago, University of Chicago Press.

41. Artist's website, [

www.helenawalsh.com

], accessed March 2012.

42. Interview with the artist.

43. Idem.

44. Gill, Becca, “Interview with Louise Walsh", [

http://totaltheatre.org.uk

], accessed March 2012.

45. Michelle Brewer, "Abortion on the Island of Ireland, Crisis, Contradiction and Colonization", Canadian Women Studies, vol. 17, No. 3, p. 61.

46. Jeanie Forte, op. cit., p. 220.

47. Cheri Gaulke, “Acting Like Women: Performance Art of the Women's Building”, High Performance Magazine, p. 13-21, Fall-Winter 1980. Reproduced in Linda Frye Burnham and Steven Durland, The Citizen Artist: 20 Years of Art in the Public Arena, An Anthology from High Performance Magazine 1978-1998, New York, Critical Press, 1998.

48. Laura Mulvey, Visual and Other Pleasures, Palgrave, Basingstoke, 1989, p. 19.

49. Jeanie Forte, op. cit., p. 228.

50. In 2004 in Cracow, The League of Polish Families attacked a peaceful demonstration of gays and lesbians so that "the former war of the genders is being replaced by a new conflict of sexual orientations" (Leszkowicz).

51. See Ann Davey Orr's editorial, Circa, n², January-February 1982, p. 4.

52. Marina Abramovic curated Marking the Territory, a performance festival hold at the IMMA in 2010.

53. Michel Foucault, History of Sexuality I, 1978, p. 151.

54. Maher herself had produced, besides the Snail Chronicles that inspired Coogan, a series of self-portraits in which she adorned herself with hand-made necklaces made up of dead animal's tongues or hearts (Necklace of Tongues (2001), or Collar (2003).

55. London Bridge Station, 2007.

56. Patrick Duggan, “The Touch and the Cut: an Annotated Dialogue with Kira O'Reilly”, Studies in Theatre and Performance, vol. 29, No. 3, 2009, p. 320.

57. Kuppers, Petra, The Scar of Visibility: Medical Performances and Contemporary Art, Minneapolis, University of Minnesota Press, 2007, p. 8.

58. Gallasch,

Keith, “Blood Lines”,

National Review of Live Art

,

[

http://www.realtimearts.net/article/issue52/9278

], accessed March 2012.

59. Duggan, op. cit., p. 307. 
60. Quoted by Marvin Carlson, Performance, A Critical Introduction, New York, Routledge, 1996 ( $2^{\text {nd }}$ ed.), p. 164-165.

61. Jeanie Forte, op. cit., p. 226.

62. Crzegorz Dziamski and Malgorzata Sady, Suite \& fin: Pologne, Inter : art actuel, Numéro 43, printemps 1989, p. 50-76, [

http://id.erudit.org/iderudit/46883ac

], p. 71, accessed March 2012.

63. Natalia LL, Natalia LL, "Teoria głowy” (Theory of Head), Exit 6 1991, p. 224.

64. Dziamski, op. cit., p. 76.

65. Ryan, op. cit., p. 94. See also Imelda Whelehan, Modern Feminist Thought: From the Second Wave to 'Post-Feminism', Edinburgh, Edinburgh University Press, 2000, p. 148.

66. Clodagh Corcoran, "Pornography: The New Terrorism", in A Dozen Lips, Dublin, Attic Press, 1994, p. 1-21, p. 18.

67. Interview with the artist.

68. Ariel Levy, Female Chauvinist Pigs: Women and the Rise of Raunch Culture, New York, Free Press, 2005, p. 26-27.

69. Kowalczyk, op. cit., p. 15.

70. Mulvey, op. cit., p. 17.

71. The actionist music and visual art group, including Zbigniew Libera and Jerzy Truszkowski, showed paintings, performed concerts or happenings in Warsaw.

\section{ABSTRACTS}

In Poland through the 1970s alternative spaces enabled the flourishing of a feminist artistic avant-garde. In Ireland, in the 1970s and 1980s the artists were primarily concerned with the Troubles, the persistence of cultural nationalism and its impact on their identities. In both countries, the 1990s were a time of heated discussions, putting the female body in the limelight: as the Church took on a considerable role in the debates over abortion, contraception, and divorce, feminist artists addressed the denial of the corporeality of the women's body and took over its representation. The Europeanization and secularization of the two countries spurred these artists to evoke sexuality more openly and to challenge the perceptions of femininity and womanhood.

Si en Pologne les années 1970 virent l'émergence d'une avant-garde artistique féministe, rendue possible par l'existence d'espaces d'exposition alternatifs, en Irlande les artistes femmes des années 1970-1980 se montraient préoccupées par les «Troubles» et par la persistance d'un nationalisme culturel qui façonnait leur identité. Les années 1990 furent marquées par de vifs débats qui placèrent le corps de la femme au centre de l'arène politique. L'Eglise prenant part aux débats sur l'avortement, la contraception ou le divorce, plusieurs artistes féministes critiquèrent son refus de considérer le corps charnel de la femme et se sont réapproprié la représentation de 
leur corps. L'européanisation et la sécularisation des deux pays ont encouragé ces artistes à évoquer la sexualité plus ouvertement et à bousculer les perceptions de la féminité.

\section{INDEX}

Mots-clés: arts visuels, sexualité, féminisme et post-féminisme, femmes et féminité, Irlande questions économiques et sociales, Église catholique d'Irlande, rôle social de l'artiste, corps Keywords: visual arts, social role of the artist, Irish Catholic Church, women and femininity, feminism and post-feminism, Ireland - socio-economic issues, sexuality, body

\section{AUTHOR}

\section{VALÉRIE MORISSON}

Université de Bourgogne - Dijon 